above-mentioned etherial solution of fat be kept at a temperature of $37^{\circ} \mathrm{C}$. until the ether has evaporated, whilst the greater portion of the fat was in a liquid state, yet some of it had solidifi $s$ on the sides of the test-tube. This would seem to indicate that it is possible that some of the fats which bave a lower melting point solidify in the frees before defæcation takes place; consequently it is not surprising that Dr. O. J. Vlirland reported that the motions were clay-coloured when passed. I would suggest that the cream or primrose colouring of some of the motion was due to the fat plus undigested starch, for the latter is said to produce a yellow colour in the frees.

I am, Sirs, yours faithfully,

Denmark-hill, S.E., Dec. 26th, 19:5. FrANk A. WVatikiss.

\section{THE LEPTUS AUTUMNALIS.}

\section{7o the Editors of THE LANCET.}

SrRs,-From Dr. W. MrcLonnan's paper on this subject in THE LANCET of Dec. 16sh I suppose we may assume that the "harvester" or "harvest bug" is less well known in Scotland than in England. These larvæ are troublesome from the end of July to the beginning of September in chalky districts and places near the sea and become a serious pest during hot, dry summors. I have never noticed that men are more affected than women but there is no doubt that the larva burrow; into the true skin. Those who walk without protection are bitten below the knees, about the ankles and in the popliteal spaces if the field grass has been at a'l long, while those who in cautiously lie on the ground are attacked between the shoulders. Sportsmen try to protect their legs with paraffin and it misht be worth while to anoint the legs with an infusion of coarse tobacco or with citronella oil, which i valuable for kesping off midges and mosquitoes. But I have found that the best and safest remedy after being bitten is some variation of the sulphur ointment to which so many generations have been indebted to get rid of scabies. The oiatment allays the irritation which, in sen-itive people, becomes almost unbear ible.

I am, Sirs, yours faithfully,

Cavendish-square, W., Dec 2ith, $1905 . \quad$ F. M. SAXDWITH.

\section{THE HETEROGENETIC ORIGIN OF CANCER CELLS.}

To the Editors of THE LANCET.

Sirs - In his important lecture on Cancer is a Parasitic Disease Mr. H. T. Butlin suggests, though he confesses to some hesitation in putting a speculation so heterodox into words, that the malignant cell is a parasite arising by heterogeretic transformation of the tissue cells. Hauser's conclusions in this re-pect are support-d by Professor J. B. Farmer, Mr. C. E. Walker, and Mr J. E. S. Moore who say, " in this and in other cases that we have examined we were irresistibly driven to the conclusion that the growth had not originated from a single cell, or even from a few cells, but was baing evolved by the direct conversion of a great many elements definitely functionating as mucous cells into those of a truly malignant type." In an abstrast of a paper by the same anthors read before the $R$ syal Society on Dec. 7th, 1905, I read, "they find evidence, derived from all the poung growths they have eximined, of a transmutation of functional somatic into cancerous cells." This, then, would appear to be a definite process of heterogenesis, such as D:. H. Charlton Bastian has long been describing for different kin ls of independent living units, such as monads, amoebr, ciliated infusori, sc. The analogy is all the more complete seeing that we are told by Dr. E. F. Bashford ${ }^{3}$ that cancer cells have, like lower organisms, an almost infinite capacity for self-multiplication. Thus he says :-

The transference of cancer cells from one mouse to another, therefore afforts then an opportunity for continuing to grow in a succession of anima enoig ; four years after the death of the mouse in which it arrse. ..... II ir four yente sucersively all of which are now dead yet the tunour cells themselves are multiplying in other mice as actively as over and producing enormuls masses of tiosue.

\section{Transactions of the Pathological Society, 1905, p. 379.}

2 See his "Studies in Ileterosenesis" Williams and Nurgate. 1903, and h's "Nature and Origin of Living Matter." Fisher Unwin, 1905.
Is not this, then, a new race of organisms, of very definite and specific kind, which has arisen by heter. gene-is in the tissue cells of another organism? Dr Bashford's work lears him to say: "Sporadically tle disease arises de novo in each organism attacked and appears to be a process to which the tissues of the most divergent organisms are liable in the old-age period of life." The notion that cancer was "started in remote geological ages" (just as orthodox biologists consider that all lowly species were started) and that this primæval cancer was the source from which others have descended is one which he regards as "entirely irrational." Thus we cannot, with Mr. Butlin, say "cancer is a parasitic disease" unless we follow up such a statement with the most inportant qualifications. All parasitic diseases are supposed to owe their origin to processes of infection or contagion-to the entrance of a living thing into the body of the host affected. Here, however, we seem to have evidence of the de novo origin of the cancer in each person attacked, and, according to Hauser, Farmer, Walker, and Moore, the multiple origin of its cells in the tissues affected by the hitherto discredited process of het rogenesis.

I am, Sirs, pours faithfully,

C. W. SALEEBY, M.D. Edin.

Greville-place, N.W., Dec. 22nd, 1905.

\section{PROPOSED ASSOCIATION OF HOLDERS OF ASSISTANTS: CERTIFICATE OF SOCIETY}

\section{OF APOTHECARIES.}

To the Editors of THE LANCET.

SIrs, - With the aid of some of my colleagues in the public service I am desirous of forming an association of holders of the assi-tants' certificate of the Society of Apothecaries of London. I therefore beg to ask you to be good enough to give me your valuable assistance by allowing me to make an appeal in your columns to all who may be interested in the matter, especizlly to those holding appointments in the public and hospital services. Several of us have felt for some time past that our interests are greatly imperilled through lack of organisation and we feel that the time is ripe to combine to enable us to protect the undoubted privileges and advantages which we possess.

I may say that I have had a personal interview with $\mathrm{Mr}$. A. M. Upton, clerk to the Suciety of Apothecaries, who assured me of the sympathy and support ot that body. $\mathrm{He}$ also promised a very substantial aid by offering, subject to the approval of the master and wardens, to place a room at the Society's hall at our disposal in which to meet and discuss the several questions which are now agitating the whole dispensing body. I therefore earnestly invite all those who may be willing to join such an association to forward to me their names and addresses at their earliest convenience. Should this appeal meet with a satisfactory response I will at once take steps to call a meeting. I am, Sirs, yours faithfully,

AlBERT Howell

Hackney Union Dispensary. Rosebers-place, Dalston, N.E. Dec. 27 th, 1905 .

\section{THE INFLUENCE OF POSTURE ON THE NORMAL CARDIAC SOUNDS AND 1) UINESS. \\ To the Editors of THE LANCET.}

SIRs, - Your report of Dr. W. Gordon's paper on this subject in 'THE LANCET of Nov. 18th (p. 1473) must, in my opinion, have excited the special interest of radiographers. Perhaps the following note may be of general interest. In measuring the exact cardiac outlines by means of the $x$ rays, using the method known as "ortho-diagraphy" which enables the taking of a parallel projection of the shadow and therefore of the exact outlines of the object, the following is found. In the erect posture the shadow of the heart is narrower in width and at a lower level in the thorax; the longitudinal axis of the organ assumes a position nearer to vertical. In the recumbent position the reverse takes place: the heart is seen higher up in the thorax, broader in width, and lying more horizontally. Analogies to these conditions exist in respiration, inspiration bringing about analogous con ditions to the erect posture and expiration to the recumbent one. I am, Sirs, yours faithfully. Bad Nauheim, Dec. 20th, 1905 